\title{
Complexity of Organizational Identification: Measuring Ambivalent Identification
}

\author{
Shohei Hayashi ${ }^{1}$ \\ ${ }^{1}$ Graduate school of business administration, Kobe University, Japan \\ Correspondence: Shohei Hayashi, Graduate school of business administration, Kobe University, 2-1, Rokkodai, \\ Nada, Kobe 657-8501, Japan. E-mail: hayashi.shohei.jp@gmail.com
}

Received: November 4, 2013

Accepted: November 18, 2013 Online Published: December 23, 2013

doi: 10.5539/ibr.v7n1p49

URL: http://dx.doi.org/10.5539/ibr.v7n1p49

\begin{abstract}
Organizational identification is the root construct of organizational phenomena. Many researchers have examined this concept in terms of identification (positive) and disidentification (negative). However, recently some researchers began focusing on ambivalent identification, which refers to the simultaneous appearance of both identification and disidentification. This new concept is likely to shed light on organizational phenomena that cannot be demonstrated by identification or disidentification alone. This study focuses on ambivalent identification. We started by creating a concrete definition for this concept. Further, we tried to develop a valid measurement for it through pilot and main studies. Consequently, we defined this concept in terms of cognitive and affective aspects and observed the complexity associated with ambivalent identification.
\end{abstract}

Keywords: ambivalent identification, scale development

\section{Introduction}

Innovation in products, services, and the organization itself is required for achieving sustainable growth. The source of innovation is creativity (Amabile, 1997). In other words, innovation in the organization depends on how the organization manages and applies its members' creativity.

Organizational identification (OID) is the root construct in organizational phenomena (Albert, Ashforth, \& Dutton, 2000). OID is related to the self-identity and decision-making of individuals (Tompkins \& Cheney, 1985). Consequently, OID influences organizational phenomena because every organization is an aggregation of individuals. Assuming that innovation is an organizational phenomenon, it is likely that OID influences innovation when the organization actively promotes it. However, if one considers what is called "the dark side of OID" (c.f., Dukerich et al., 1998; Elsbach, 1999), the following contradictions appear. According to Pratt (2000), an organization that employs members who identify strongly with it would have increased homogeneity, which would consequently lead to groupthink. Thus, it becomes difficult for such an organization to change its strategy in order to adapt to environmental changes. Innovation is likely to occur with the existence of diverse viewpoints (Verganti, 2011). If creativity results from having a different viewpoint, then OID, which approximates members' personal-identity to organizational identity, may hinder creativity. However, because OID is thought to be a requirement for organizational phenomena, organizations should consider it seriously. That is, organizations may experience dilemma about whether to stimulate creativity or support OID. However, are these concepts necessarily incompatible?

Many researchers discuss the phenomenon of OID only in terms of positive and negative vectors (i.e., OID and organizational disidentification). However, recently some researchers have identified not only two vectors of identification but also ambivalent identification (AID), which is the simultaneous appearance of both OID and disidentification (Dukerich, Kramer, \& Parks, 1998; Kreiner \& Ashforth, 2004; Pratt, 2000; Sluss \& Ashforth, 2007). According to Dukerich et al. (1998), a member who identifies ambivalently with the organization perceives conflicting feelings over it and engages in whistle-blowing and behavior change in order to resolve this conflict. While studying ambivalence, which is a super-concept of AID, Fong (2006) applied informational theories of emotion. He demonstrated that emotional ambivalence led to the interpretation that the person was in an unusual environment, and accordingly led to uncommon reactions to the environment. These uncommon reactions were based on creative thinking. As mentioned above, it is likely that research on AID could overcome the problem that previous OID studies had. 
However, as a concept, AID is in the early stage of development. For example, although Pratt (2000) argued that AID is a partial failure of OID, Dukerich et al. (1998) argued that AID occurs when both OID and disidentification appear strongly. Their disagreement exemplifies the inconsistency in the conceptualization of AID. The reasons for this inconsistency may be (1) few studies have investigated this issue, (2) no definition has been established, (3) empirical research on this topic is difficult because scales to measure AID are underdeveloped (Note 1), and (4) inductive research is difficult because it is difficult to comprehend the phenomenon of AID through observation and interview (Note 2). The present study focuses on the resolution of points (2) and (3), and accordingly aims to contribute to (1).

Most studies on OID have treated identification as a cognitive concept. However, Tajfel (1978) defined social identity as "that part of an individual's self-concept which derives from his knowledge of his membership of a social group (or groups) together with the value and emotional significance attached to that membership," essentially stating that social identity consists of both cognitive and affective dimensions. Therefore, studies on OID in which social identity theory (Tajfel \& Turner, 1979) is central, should consider both cognitive and affective dimensions (Harquail, 1998; Johnson, Morgeson, \& Hekman, 2012; Van Dick, 2001). Accordingly, the present study considers AID as a cognitive and affective construct.

\section{Definition of Ambivalent Identification}

Bleuler (1911) defined ambivalence as "the simultaneous existence of strong feelings of love and hate toward the same object" (cf. Eidelberg, 1968; Luescher \& Pillemer, 1998). Similarly, Alexander (1951), Argyris (1957), and Freud (1913), defined ambivalence as the co-existence of conflicting feelings directed toward the same object. However, Sincoff (1990), defined ambivalence as "overlapping approach-avoidance tendencies, manifested behaviorally, cognitively, or affectively, and directed toward a given person or experience." Although the former four researchers treated ambivalence affectively, the latter treated it both cognitively and affectively.

Ambivalence has been measured through subjective and objective approaches (Constarelli \& Colloca, 2004). Subjective approach refers to the direct measurement of ambivalence by using a scale. On the other hand, objective approach refers to the development of an algorithm that factors in positive and negative attitudes to calculate ambivalence toward a particular object. Studies that use this objective approach are based on the view of Scott (1966), who stated that the greater and more equal the opposite tendencies, the higher the degree of ambivalence (e.g., Costarelli \& Colloca, 2004; Kaplan, 1972; Moore, 1972; 1973; Tompson, Zanna, \& Griffin, 1995). These studies that use objective approaches defined ambivalence as an attitudinal concept. That is, they treated ambivalence as manifold concepts because attitude consists of behavior, affect, and cognition (Kelman, 1958).

In addition, Scott (1966) suggested considering the weight of each component. The present study synthesized these suggestions and defined ambivalence as "the simultaneous and equal existence of the opposite feeling or thinking toward the same object." This definition of ambivalence should then operate on the definition of AID. Although some studies have examined AID (e.g., Dukerich et al., 1998; Pratt, 2000; Sluss \& Ashforth, 2007) (Note 3), its definition has not been explicitly stated. According to Kreiner and Ashforth (2004), AID refers to the idea that "one can simultaneously identify and disidentify with one's organization (or aspects of it)." Their definition is vague because OID and disidentification were not clearly defined. In fact, because they considered only the cognitive aspect of OID, it is more likely that this definition does not accurately reflect the concept of ambivalence.

We examined various definitions of OID, which confirmed that most researchers defined the cognitive or affective dimensions of OID. For instance, researchers who considered the cognitive aspect, defined OID as "a perceived oneness with an organization and the experience of the organization's successes and failures as one's own" (Mael \& Ashforth, 1992); "the degree to which a member defines him- or herself by the same attributes that he or she believes define the organization" (Dutton, Dukerich, \& Harquail, 1994); "a psychological state wherein individuals perceive themselves to be part of a larger organization" (Rousseua, 1998); and "an individual's belief about his or her organization becomes self-referential or self-defining" (Pratt, 1998). On the other hand, the researchers who considered the affective aspect defined OID as "the degree to which an individual values having a specific organizational identity" (Harquail, 1998); "the feelings individuals experience about themselves in relation to the social referent and the value they place on that social identity" (Johnson \& Morgeson, 2005); and "an individual's positive feelings about being one with a group" (Johnson et al., 2012). Observing the difference between both dimensions plainly, OID seems to be the perception and feeling of individuals as organizational members (Harquail, 1998), the perception and feeling of oneness with the group (Johnson et al., 2012), and the emotional attachment one has to this group and the knowledge of a certain group membership (Van Dick, 2001). Assimilating these ideas, the present study thus defined cognitive OID as "the degree to which a member perceives himself or herself as part of an organization" and affective OID as "the degree to which a member holds positive 
feelings toward the organizational identity."

Based on these definitions of both cognitive and affective OID and ambivalence, AID is therefore defined cognitively as "the process in which a member simultaneously and equally perceives and does not perceive himself or herself as part of an organization," and affectively as "the process in which member simultaneously holds both positive and negative feelings towards organizational identity in equal parts."

\section{Measuring Ambivalent Identification}

We first searched the existing literature for published scales that measured OID and disidentification, by using "word identification," and found 26 relevant articles (Note 4). The items in these scales were then classified into cognitive and affective OID based on the above definitions and the study of Johnson et al. (2012). Finally, 22 items were derived for the cognitive dimension and 13 items were derived for the affective dimension.

These items were then transformed into sentences that could be used to measure AID whilst referencing the above definitions of AID, items for AID by Kreiner and Ashforth (2004), and items for ambivalence (e.g., Aaker, Drolet, \& Griffin, 2008; Priester \& Petty, 1996; Riketta, 2000; Riketta \& Ziegler, 2006).

\subsection{Scale Development}

After developing a scale to measure AID by using the above items, we attempted to establish its validity. In this case, this study followed Hinkin's procedure (Hinkin, 1995; 1998; Hinkin \& Tracey, 1999). The procedure is composed of the following three steps: (1) content validity assessment, (2) item reduction, and (3) confirmatory factor analysis.

The assessment of content validity followed the procedure of Hinkin and Tracey (1999). Respondents first rated each of the 35 AID items according to the extent to which they believed the items were consistent with each of two dimensions' definitions of AID. Response choices ranged from 1 (not at all) to 5 (completely). The definition of one of the two dimensions was presented at the top of each page of the questionnaire. The results were then used for explanatory factor analysis.

Prior to conducting factor analysis, we examined the inter-item correlations of the variables and any variable that correlated at less than .40 with all other variables were excluded from the analysis. In this case, respondents rated the 35 AID items obediently. Thus, the items used here were different from the items used to assess content validity. Afterwards, explanatory factor analysis with varimax rotation was conducted. The criterion used to support the theoretical distinction was an eigenvalue greater than 1 (Kaiser criterion) and a scree test of the percentage of variance explained. Finally, to assess internal consistency reliability, Cronbach's alpha was calculated for each component. A Cronbach's alpha higher than .70 was considered to indicate good internal consistency reliability. Confirmation factor analysis was then conducted and construct validity was tested by goodness-of-fit indexes. This study used chi-square values (Note 5), CFI, RMSEA, GFI, and AGFI as goodness-of-fit indexes.

We conducted (1) a pilot study to eliminate extra items and modify the items, and (2) the main study to develop the scale for AID.

\subsubsection{Pilot Study}

\section{Method}

Questionnaires were distributed to six seminars in two Japanese universities. The purpose of this questionnaire was explained in the classroom, before distributing it. One hundred and thirteen undergraduates responded to the questionnaire. The number of valid responses was $60(53.1 \%)$. Respondents consisted of 38 men $(63.3 \%)$ and 22 women (36.6\%); 31 students were in the third grade (51.7\%), 26 in the fourth grade (43.3\%), and three did not specify their grades $(4.9 \%)$.

Results

\section{(1) Content Validity Assessment}

Explanatory factor analysis with varimax rotation was conducted to determine content validity. There were nine components with eigenvalues greater than 1 . However, the examination of a scree test supported two components; the percentages of variance explained were $24.7 \%$ and $20.9 \%$ respectively. Finally, ten out of the 13 affective items were left. Eleven out of the 22 cognitive component items were left.

\section{(2) Initial Item Reduction}

The correlation analysis found eight items of the cognitive dimension and six items of the affective dimension to have a correlation of more than .4 with all other variables. Then, explanatory factor analysis with varimax rotation was conducted for these 14 items. This analysis identified two components that were labeled as affective and 
cognitive respectively; the percentages of variance explained by the affective and cognitive components were $31.5 \%$ and $26.3 \%$ respectively. No items were eliminated by this explanatory factor analysis. The internal consistency (Cronbach's alpha) was .741 for the affective component and .554 for the cognitive component.

\section{(3) Confirmatory Factor Analysis}

This pilot study aimed at eliminating the extra items and modifying the sentences describing the items and therefore did not conduct confirmatory factor analysis. We asked respondents for their feedback regarding the questionnaire and suggestions for improving of the sentences. Consequently, we could make improvements according to the feedback by modifying items that were difficult to understand, before conducting the main study.

\subsubsection{Main Study}

\section{Method}

The revised questionnaire was distributed during a class in the university. The purpose of this questionnaire was explained in the classroom, before distributing it. One hundred and nineteen undergraduates responded to the questionnaire. The number of valid responses was 37 (31.1\%). The respondents consisted of 24 men $(64.9 \%)$ and 13 women $(35.1 \%) ; 15$ students were in the second grade $(40.5 \%), 10$ in the third grade $(27.0 \%), 11$ in the fourth grade $(29.7 \%)$, and 1 in the fifth grade $(2.7 \%)$.

Table 1. Factor loadings for content validity assessment

\begin{tabular}{lll}
\hline Item & Affective AID & Cognitive AID \\
\hline Affective item 1 & .752 & \\
Affective item 2 & .852 & \\
Affective item 3 & .710 & \\
Affective item 4 & .822 & \\
Affective item 5 & .701 & \\
Affective item 6 & .849 & .677 \\
Cognitive item 1 & & .810 \\
Cognitive item 2 & & .796 \\
Cognitive item 3 & & .805 \\
Cognitive item 4 & & .789 \\
Cognitive item 5 & & .804 \\
Cognitive item 6 & & .054 \\
Cognitive item 7 & & $35.4 \%$ \\
Cognitive item 8 & 5.498 & .913 \\
Eigenvalue & $43.5 \%$ & \\
Percentage of variance explained & & \\
\hline
\end{tabular}

Results and Discussion

\section{(1) Content Validity Assessment}

An explanatory factor analysis with varimax rotation was conducted and the Kaiser criterion identified two components. The percentages of variance explained were $43.5 \%$ and $35.4 \%$ respectively. All affective items showed high factor loadings. Seven of the eight cognitive items showed high factor loadings (see Table 1 for details). Therefore, it may be inferred that the questionnaire had content validity.

(2) Initial Item Reduction

The correlation analysis identified six items in the cognitive dimension and six items in the affective dimension that had correlation coefficients of more than .4 with all other variables (Table 2). Following this, explanatory factor analysis with varimax rotation was conducted for these 12 items. The results revealed two components that were labeled as affective and cognitive respectively; the percentages of variance explained in Table 1. Factor 
loadings for content validity assessment of affective and cognitive components were $39.7 \%$ and $27.9 \%$ respectively (see Table 3 for details). No items were eliminated after this explanatory factor analysis. The internal consistency (Cronbach's alpha) was .883 for the affective component and .768 for the cognitive component.

Table 2. Intercorrelations for initial item reduction

\begin{tabular}{|c|c|c|c|c|c|c|c|c|c|c|c|c|c|}
\hline & $\mathrm{C} 1$ & $\mathrm{C} 2$ & $\mathrm{C} 3$ & $\mathrm{C} 4$ & C5 & C6 & C8 & $\mathrm{A} 1$ & $\mathrm{~A} 2$ & $\mathrm{~A} 3$ & A4 & A5 & A6 \\
\hline Cognitive 1 & 1 & & & & & & & & & & & & \\
\hline Cognitive 2 & .092 & 1 & & & & & & & & & & & \\
\hline Cognitive 3 & $.544 * *$ & .281 & 1 & & & & & & & & & & \\
\hline Cognitive 4 & $.732 *$ & .039 & $.464 * *$ & 1 & & & & & & & & & \\
\hline Cognitive 5 & $.387^{*}$ & .147 & .216 & .266 & 1 & & & & & & & & \\
\hline Cognitive 6 & .204 & .169 & $.384^{*}$ & .241 & $.508 * *$ & 1 & & & & & & & \\
\hline Cognitive 8 & .254 & .113 & $.437 * *$ & .021 & $.510^{* *}$ & .295 & 1 & & & & & & \\
\hline Affective 1 & .225 & $.433 * *$ & $.415^{*}$ & .243 & .164 & .168 & .204 & 1 & & & & & \\
\hline Affective 2 & .183 & $.339^{*}$ & $.391 *$ & .232 & .122 & .109 & .158 & $.532 * *$ & 1 & & & & \\
\hline Affective 3 & .206 & .216 & $.345^{*}$ & .301 & $.364^{*}$ & $.425^{* *}$ & .279 & $.464 * *$ & $.501 * *$ & 1 & & & \\
\hline Affective 4 & .266 & .133 & .199 & $.375^{*}$ & .166 & $.347^{*}$ & .158 & $.547 * *$ & $.498^{* *}$ & $.586 * *$ & 1 & & \\
\hline Affective 5 & .184 & $.393^{*}$ & .222 & .225 & .288 & .202 & .178 & $.571 * *$ & $.733 * *$ & $.670 * *$ & $.601 * *$ & 1 & \\
\hline Affective 6 & .099 & .305 & .093 & .179 & $.348^{*}$ & .093 & .103 & $.529 * *$ & $.478^{* *}$ & $.529 * *$ & $.410^{* *}$ & $.756^{* *}$ & 1 \\
\hline
\end{tabular}

$* *: \mathrm{p}<.01, *: \mathrm{p}<.05$.

Table 3. Factor loadings for initial item reduction

\begin{tabular}{lll}
\hline Item & Affective AID & Cognitive AID \\
\hline Affective item 1 & .749 & \\
Affective item 2 & .810 & \\
Affective item 3 & .687 & \\
Affective item 4 & .658 & \\
Affective item 5 & .907 & \\
Affective item 6 & .790 & .871 \\
Cognitive item 1 & & .691 \\
Cognitive item 2 & & .859 \\
Cognitive item 3 & & .789 \\
Cognitive item 4 & & .817 \\
Cognitive item 5 & & .871 \\
Cognitive item 6 & & 3.294 \\
Cognitive item 8 & 4.763 & $27.9 \%$ \\
Eigenvalue & $39.7 \%$ & \\
Percentage of variance explained & & \\
\hline
\end{tabular}


Table 4. The scale for ambivalent identification with an organization

\begin{tabular}{ll}
\hline No. & Items \\
\hline Affective item 1 & I feel pride and insulted in being part of this university \\
Affective item 2 & I am glad and sorry to belong to this university \\
Affective item 3 & I regret and am satisfied that I belong to this university \\
Affective item 4 & I am proud of and also complain when I tell people who I study with \\
Affective item 5 & I feel good and bad when I think about myself as a member of this university \\
Affective item 6 & I feel happy and sad to be a student in this university \\
Cognitive item 1 & I see and am indifferent of myself as belonging to this university \\
Cognitive item 3 & I am very interested and uninterested in what others think about this university \\
Cognitive item 4 & Belonging to this university is an important and unimportant part of my self-image \\
Cognitive item 5 & It is important and insignificant to me that others do not criticize this university \\
Cognitive item 6 & Being a member of this university has very little and very much to do with how I feel about myself \\
Cognitive item 8 & If this university were criticized, it would influence and not influence how I think about myself \\
\hline
\end{tabular}

\section{(3) Confirmatory Factor Analysis}

The goodness-of-fit indexes of the confirmatory factor analysis indicated that this model fitted the data well $\left(\chi^{2}\right.$ $(46)=47.678 ; \mathrm{CFI}=.991 ; \mathrm{GFI}=.904 ; \mathrm{AGFI}=.802 ; \mathrm{RMSEA}=.032)$. Therefore, the questionnaire has construct validity. The analysis resulted in six affective items and six cognitive items (see Table 4 for details).

\section{Discussion}

The present study makes at least two contributions to existing knowledge. Firstly, AID was defined more strictly here than in previous studies, where vaguely defined concepts hindered the discussion of the phenomenon. As AID had not been clearly defined until now, defining it here may lead to and form the basis for future research. Secondly, this study developed a scale to measure AID. As mentioned before, previous researchers had not studied AID empirically because no such scale had been developed until now. Thus, creating this scale contributes greatly to the development of future empirical studies.

Discussing OID cognitively means discussing the cognitive distance between organizational identity and self-identity and the perceived vector. Previously, this discussion was conducted in terms of two axes: "near or far" and "approaching or leaving." However, bringing the concept of ambivalence into this discussion leads to a new angle - "near and far" and "approaching and leaving." This point was overviewed previously, suggesting the complexity of the concept of identification. The present study could very well provide a lead to understand and acknowledge this complexity.

Kreiner and Ashforth (2004) have attempted to measure AID. Although they defined OID cognitively, items in their tool that measured AID consisted of both cognitive and affective dimensions. Thus, there was a disagreement between the scale and the definition used in the study, which affected the scale's content validity. Furthermore, because they did not show how their AID measurement was developed, the construct validity was not also manifested. In contrast, this study considered both dimensions, constructed the items deductively, and tested for content validity. Accordingly, this study is more likely to avoid similar problems of content validity.

As shown from both, the pilot and main studies, the sample size is not sufficient to establish validity (particularly construct validity). The percentage of valid responses suggested that items that looked like "double-barreled" questions might have caused confusion among respondents. However, this problem may be attributed to not the present study but the inherent ambiguity of AID. Considering the previous, subjective approach to AID, these items look like double-barreled questions. Although the objective approach mentioned above (Costarelli \& Colloca, 2004) may be useful to solve this problem. Previous studies did not find high intercorrelations between subjective and objective approaches (e.g., Tompson et al., 1995). That is, the objective approach could not be substituted for the subjective approach. Therefore, it is important to acknowledge that we need to develop a valid subjective approach first in order to develop a valid objective approach.

We used undergraduate students as sample. Compared to employees in a company, a university does not work on the undergraduates' socialization to a great extent. Thus, it is likely that they do not pay attention to the 
university's identity. In addition, Kreiner and Ashforth (2004) argued that when an organization sends inconsistent or contradictory messages to its stakeholders regarding what it stands for, and why and when an organization demands incompatibly from within a give role, AID would occur. These antecedents are all organizational factors. More employees may identify ambivalently with their organization than students may with their university, because the environment requires different behavior from the employees. Therefore, if we use employees instead of undergraduates as the participants, above problems might be resolved. That is, it is likely that employees may have responded to items for AID and consequently we could have gathered a sufficient sample size to establish validity.

Finally, if more future studies focus on AID and its measurement, AID would become a measurable concept, the mechanism of OID might be demonstrated more effectively, and the relationship between creativity and OID would be manifested.

\section{Conclusion}

This study focused on defining AID and developing the scale to measure it. Firstly, we examined some concepts of ambivalence, cognitive OID, and affective OID, accordingly defined cognitive AID as "the process in which a member simultaneously and equally perceives and does not perceive himself or herself as part of an organization," and affective AID as "the process in which member simultaneously holds both positive and negative feelings towards organizational identity in equal parts." Secondly, on the basis of above definitions, the scale was developed through pilot and main study. As a result, affective and cognitive scale consists of twelve items (6 affective items and 6 cognitive items).

Many researchers have not empirically tested the hypothesis about AID. The reasons are for the problem of definition and scale as mentioned above. We proposed both, so future researches which tested AID empirically may increase. AID is important concept because it is likely to shed light on organizational phenomena that cannot be demonstrated by identification or disidentification alone. Although it may be difficult for the person to grasp the person's ambivalent state by him/her-self, if this problem will be resolved in the future, this new concept would demonstrate many organizational phenomena. Thus, this study contributes to the foundation for AID researches.

\section{References}

Aaker, J., Drolet, A., \& Griffin, D. (2008). Recalling Mixed Emotions. Journal of Consumer Research, 35(2), 268-278. http://dx.doi.org/10.1086/588570

Abrams, D., Ando, K., \& Hinkle, S. (1998). Psychological attachment to the group: Cross-cultural differences in organizational identification and subjective norms as predictors of workers' turnover intentions. Personality and Social Psychology Bulletin, 24(10), 1027-1039. http://dx.doi.org/ 10.1177/01461672982410001

Albert, S., Ashforth, B. E., \& Dutton, J. E. (2000). Organizational identity and identification: charting new waters and building new bridges. The Academy of Management Review, 25(1), 13-17. http://dx.doi.org/10.5465/AMR.2000.2791600

Alexander, F. (1951). Fundamentals of psychoanalysis. New York: W. W. Norton \& Company, Inc.

Amabile, T. M. (1994). Motivating creativity in organization: on doing what you love and loving what you do. California Management Review, 40(1), 39-58. http://dx.doi.org/10.2307/41165921

Argyris, C. (1957). Personality and organization: the conflict between system and the individual. New York: Harper.

Ashforth, B. E. (1998). Becoming: how does the process of identification unfold? In D. A. Whetten \& P. Godfrey (Eds.), Identity in Organizations (pp. 213-222). Thousand Oaks, Calif.: Sage Publications.

Bartel, C. A. (2001). Social comparisons in boundary-spanning work: Effects of community outreach on members' organizational identity and identification. Administrative Science Quarterly, 46(3), 379-413. http://dx.doi.org/10.2307/3094869

Bergami, M., \& Bagozzi, R. P. (2000). Self-categorization, affective commitment and group self-esteem as distinct aspects of social identity in the organization. British Journal of Social Psychology, 39(4), 555-577. http://dx.doi.org/10.1348/014466600164633

Bhattacharya, C. B., \& Elsbach, K. D. (2002). Us versus them: The roles of organizational identification and disidentification in social marketing initiatives. Journal of Public Policy and Marketing, 21(1), 26-37. http://dx.doi.org/10.1509/jppm.21.1.26.17608 
Bleuler, E. (1911). Dementia Praecox oder Gruppe der Schizophrenien. Leipzig, Germany: Franz Deuticke.

Boen, F., Vanbeselaere, N., \& Cool, M. (2006). Group status as a determinant of organizational identification after a takeover: A social identity perspective. Group Processes and Intergroup Relations, 9(4), 547-560. http://dx.doi.org/10.1177/1368430206067555

Brown, R., Condor, S., Mathews, A., Wade, G., \& Williams, J. (1986). Explaining intergroup differentiation in an industrial organization. Journal of Occupational Psychology, 59(4), 273-286. http://dx.doi.org/10.1111/j.2044-8325.1986.tb00230.x

Christensen, P. N., Rothgerber, H., Wood, W., \& Matz, D. C. (2004). Social norms and identity relevance: A motivational approach to normative behavior. Personality and Social Psychology Bulletin, 30(10), 1295-1309. http://dx.doi.org/10.1177/0146167204264480

Costarelli, S., \& Colloca, P. (2004). The effects of attitudinal ambivalence on pro-environmental behavioral $\begin{array}{llll}\text { intentions. Journal of Environmental 249-288. } & \text { Psychology, }\end{array}$ http://dx.doi.org/10.1016/j.jenvp.2004.06.001

Dukerich, J. M., Kramer, R., \& Parks, J. M. (1998). The dark side of organizational identification. In D. A. Whetten \& P. Godfrey (Eds.), Identity in Organizations (pp. 245-256). Thousand Oaks, Calif.: Sage Publications.

Dutton, J. E., Dukerich, J. M., \& Harquail, C. V. (1994). Organizational images and member identification. Administrative Science Quarterly, 39(2), 263-289. http://dx.doi.org/10.2307/2393235

Eidelberg, L. (Editor-in-chief) (1968). Encyclopedia of psychoanalysis (pp. 27-28). New York: The Free Press.

Fong, C. T. (2006). The effects of emotional ambivalence on creativity. Academy of Management Journal, 49(5), 1016-1030. http://dx.doi.org/10.5465/AMJ.2006.22798182

Fong, C. T., \& Tiedens, L. Z. (2002). Dueling Experiences and Dual Ambivalences: Emotional and Motivational Ambivalence of Women in High Status Positions. Motivation and Emotion, 26(1), 105-121. http://dx.doi.org/10.1023/A:1015198209285

Foreman, P., \& Whetten, D. (2002). Member's identification with multiple-identity organizations. Organization Science, 13(6), 618-635. http://dx.doi.org/10.1287/orsc.13.6.618.493

Freud, S. (1913). Totem and taboo. (Strachey, J. Trans.) (pp. 155-161). London: Routledge \& Kegan Paul.

Gautam, T., Van Dick, R., \& Wagner, U. (2004). Organizational identification and organizational commitment: Distinct aspects of two related concepts. Asian Journal of Social Psychology, 7(3), 301-315. http://dx.doi.org/10.1111/j.1467-839X.2004.00150.x

Hall, D. T., \& Schneider, B. (1972). Correlates of organizational identification as a function of career pattern and organizational type. Administrative Science Quarterly, 17(3), 340-350. http://dx.doi.org/10.2307/2392147

Hall, D. T., Schneider, B., \& Nygren, H. T. (1970). Personal factors in organizational identification. Administrative Science Quarterly, 15(2), 176-190. http://dx.doi.org/10.2307/2391488

Harquail, C. V. (1998). Organizational identification and the "whole person": integrating affect, behavior, and cognition. In D. A. Whetten \& P. Godfrey (Eds.), Identity in Organizations (pp. 223-231). Sage Publications, Inc.

Harris, G. E., \& Cameron, J. E. (2005). Multiple dimensions of organizational identification and commitment as predictors of turnover intentions and psychological well-being. Canadian Journal of Behavioural Science, 37(3), 159-169. http://dx.doi.org/10.1037/h0087253

Hinkin, T. R. (1995). A review of scale development practices in the study of organizations. Journal of Management, 21(5), 967-988. http://dx.doi.org/10.1177/014920639502100509

Hinkin, T. R. (1998). A brief tutorial on development of measures for use in survey questionnaires. Organizational Research Methods, 1(1), 104-121. http://dx.doi.org/10.1177/109442819800100106

Hinkin, T. R., \& Tracey, J. B. (1999). An analysis of variance approach to content validity. Organizational Research Methods, 2(2), 175-186. http://dx.doi.org/10.1177/109442819922004

Hogg, M. A., Martin, R., Epitropaki, O., Mankad, A., Svensson, A., \& Weeden, K. (2005). Effective leadership in salient groups: Revisiting leader-member exchange theory from the perspective of the social identity theory of leadership. Personality and Social Psychology Bulletin, 31(7), 991-1004. http://dx.doi.org/10.1177/0146167204273098 
Huo, Y. J., Smith, H. J., Tyler, T. R., \& Lind, E. A. (1996). Superordinate identification, subgroup identification, and justice concerns: Is separatism the problem; is assimilation the answer? Psychological Science, 7(1), 40-45. http://dx.doi.org/10.1111/j.1467-9280.1996.tb00664.x

Johnson, M. D., Morgeson, F. P., \& Hekman, D. R. (2012). Cognitive and affective identification: exploring the links between different forms of social identification and personality with work attitudes and behavior. Journal of Organizational Behavior, 33(8), 1142-1167. http://dx.doi.org/10.1002/job.1787

Johnson, M. D., \& Morgeson, F. P. (2005). Cognitive and affective identification in organizational settings. Paper presented at the 64th Annual Meeting of the Academy of Management, Honolulu, HI.

Kaplan, K. J. (1972). On the ambivalence-indifference problem in attitude theory and measurement: a suggested modification of the semantic differential technique. Psychological Bulletin, 77(5), 361-372. http://dx.doi.org/10.1037/h0032590

Kelman, H. C. (1958). Compliance, identification, and internalization three processes of attitude change. The Journal of Conflict Resolution, 2(1), 51-60. http://dx.doi.org/10.1177/002200275800200106

Kreiner, G. E., \& Ashforth, B. E. (2004). Evidence toward an expanded model of organizational identification. Journal of Organizational Behavior, 25(1), 1-27. http://dx.doi.org/10.1002/job.234

Lueshcer, K., \& Pillemer, K. (1998). Intergenerational ambivalence: a new approach to the study of parent-child relations in later life. Journal of Marriage and Family, 60(2), 413-426. http://dx.doi.org/10.2307/353858

Mael, F. A., \& Ashforth, B. E. (1992). Alumni and their alma mater: A partial test of the reformulated model of organizational identification. Journal of Organizational Behavior, 13(2), 103-123. http://dx.doi.org/10.1002/job.4030130202

Martin, R., \& Epitropaki, O. (2001). Role of organizational identification on implicit leadership theories (ILTs), transformational leadership and work attitudes. Group Processes and Intergroup Relations, 4(3), 247-262. http://dx.doi.org/10.1177/1368430201004003005

Moore, M. (1972). Moderator effects of ambivalence in attitude measurement. Paper read at the Annual Meeting of the Midwestern Psychological Association, Cleverland, Ohio.

Moore, M. (1973). Ambivalence in attitude measurement. Educational and Psychological Measurement, 33(2), 481-483. http://dx.doi.org/10.1177/001316447303300235

Moskowitz, A., \& Heim, G. (2011). Eugen Bleuler's Praecox or the group schizophrenias (1911): a centenary appreciation an reconsideration. Schizophrenia Bulletin, 37(3), 471-479. http://dx.doi.org/10.1093/schbul/sbr016

Pratt, M. G. (2000). The good, the bad, and the ambivalent: managing identification among amway distributors. Administrative Science Quarterly, 45(3), 456-493. http://dx.doi.org/10.2307/2667106

Pratt, M. G., \& Doucet, L. (2000). Ambivalent feeling in organizational relationships. In S. Fineman (Ed.), Emotion in organizations (pp. 204-226) (2nd ed.). Sage Publications. http://dx.doi.org/10.4135/9781446219850.n11

Priester, J. R., \& Petty, R. E. (1996). The gradual threshold of ambivalence: relating the positive and negative bases of attitude to subjective ambivalence. Journal of Pesonality and Social Psychology, 71(3), 431-449. http://dx.doi.org/10.1037/0022-3514.71.3.431

Randall, J., \& Procter, S. (2008). Ambiguity and ambivalence: senior managers' accounts of organizational change in a restructured government department. Journal of Organizational Change Management, 21(6), 686-700. http://dx.doi.org/10.1108/09534810810915727

Riketta, M. (2000). Discriminative validation of numerical indices of attitude ambivalence. Current Research in Social Psychology, 5(5), 63-83.

Riketta, M., \& Ziegler, R. (2006). Self-ambivalence and self esteem. Current Psychology, 25(3), 192-211. http://dx.doi.org/10.1007/s12144-006-1003-7

Riordan, C. M., \& Weatherly, E. W. (1999). Defining and measuring employees' identification with their work groups. Educational and Psychological Measurement, 59(2), 310-324. http://dx.doi.org/10.1177/00131649921969866

Roccas, S. (2003). Identification and status revisited: The moderating role of self-enhancement and self transcendence values. Personality and Social Psychology Bulletin, 29(6), 726-736. 
http://dx.doi.org/10.1177/0146167203029006005

Rotondi, T. (1975). Organizational identification and group involvement. Academy of Management Journal, 18(4), 892-897. http://dx.doi.org/10.2307/255389

Rousseau, D. M. (1998). Why workers still identify with organizations. Journal of Organizational Behavior, 19(3), 217-233. http://dx.doi.org/10.1002/(SICI)1099-1379(199805)19:3<217::AID-JOB931>3.3.CO;2-E

Sincoff, J. B. (1990). The psychological characteristics of ambivalent people. Clinical Psychology Review, 10(1), 43-68. http://dx.doi.org/10.1016/0272-7358(90)90106-K

Scott, W. (1966). Brief report: measures of cognitive structure. Multivariate Behavioral Research, 1(3), 391-395. http://dx.doi.org/10.1207/s15327906mbr0103_9

Sluss, D. M., \& Ashforth, B. E. (2007). Relational identity and identification: defining ourselves through work relations. Academy of Management Review, 32(1), 9-32. http://dx.doi.org/10.5465/AMR.2007.23463672

Smidts, A., Pruyn, A. T. H., \& Van Riel, C. B. M. (2001). The impact of employee communication and perceived external prestige on organizational identification. Academy of Management Journal, 44(5), 1051-1062. http://dx.doi.org/10.2307/3069448

Tajfel, H. (1978). Social categorization, social identity, and social comparison. In H. Tajfel (Ed.), Differentiation between Social Groups: Studies in the Social Psychology of Intergroup Relations (pp. 61-76). London: Academic Press.

Tajfel, H., \& Turner, J. C. (1979). An integrative theory of intergroup conflict. In W. G. Austin \& S. Worchel (Eds.), The Social Psychology of Intergroup Relations (pp. 33-47). Monterey, CA: Brooks/Cole.

Tompkins, P. K., \& Cheney, G. (1985). Communication and unobstructive control in contemporary organizations. In R. D. McPhee \& P. K. Tompkins (Eds.), Organizational communication: traditional themes and new irections (pp. 179-210). Thousand Oaks, Calif.: SAGE Publications, Inc.

Tompson, M. M., Zanna, M. P., \& Griffin, D. W. (1995). Let's not be indifferent about (attitudinal) ambivalence. In R. E. Petty \& J. A. Krosnick (Eds.), Attitude strength: antecedents and concequences (pp. 361-386). Mahwah, NJ: Lawlence Erlbaum Associates.

Vandenberg, R. J., Self, R. M., \& Seo, J. H. (1994). A critical examination of the internalization, identification, and compliance commitment measures. Journal of Management, 20(1), 123-140. http://dx.doi.org/10.1177/014920639402000106

Van Dick, R. (2001). Identification in organizational contexts: linking theory and research from social and organizational psychology. International Journal of Management Reviews, 3(4), 265-283. http://dx.doi.org/10.1111/1468-2370.00068

Van Dick, R., Wagner, U., Stellmacher, J., \& Christ, O. (2004). The utility of a broader conceptualization of organizational identification: Which aspects really matter? Journal of Occupational and Organizational Psychology and Aging, 77(2), 171-191. http://dx.doi.org/10.1348/096317904774202135

Van Knippenberg, D., Van Knippenberg, B., Monden, L., \& DeLima, F. (2002). Organizational identification after a merger: A social identity perspective. The British Journal of Social Psychology, 41(2), 233-252. http://dx.doi.org/10.1348/014466602760060228

Van Leeuwen, E., Van Knippenberg, D., \& Ellemers, N. (2003). Continuing and changing group identities: The effects of merging on social identification and ingroup bias. Personality and Social Psychology Bulletin, 29(6), 679-690. http://dx.doi.org/10.1177/0146167203029006001

Verganti, R. (2011). Designing breakthrough products. Harvard Business Review, 89(10), 114-120.

\section{Notes}

This paper revised the material which is presented in Europan Academy of Management, Annual Conference 2013, Doctoral Colloquium at Galatasaray University, Turkey.

Note 1. We confirms that only Kreiner and Ashforth (2004) developed the scale for AID.

Note 2. Although ambivalence was examined inductively by a few studies, these studies have a common problem. For example, Fong and Tiedens (2002), Pratt and Doucet (2000), and Randall and Procter (2008) studies the ambivalence that organization members recognized and felt. However, compared with the definition 
of ambivalence, their way to comprehend it was vague.

Note 3. Although Dukerich et al. (1998) and Sluss and Ashforth (2007) studied AID, they treated AID notionally and did not define it explicitly.

Note 4. Abrams and Hinkle (1998); Bartel (2001); Bergami and Bagozzi (2000); Bhattacharya and Elsbach, (2002); Boen, Vanbeselaere, and Cool (2006); Brown, Condor, Mathews, Wade, and Williams (1986); Christensen, Rothgerber, Wood, and Matz (2004); Foreman and Whetten (2002); Gautam, Van Dick and Wagner (2004); Hall and Schneider (1972); Hall, Schneider and Nygren (1970); Harris and Cameron (2005); Hogg, Martin, Epitropaki, Huo, Smith, Tyler, and Lind (1996); Johnson, Morgeson, and Hekman (2012); Johnson and Morgeson (2005); Kreiner and Ashforth (2004); Mael and Ashforth (1992); Martin and Epitropaki (2001); Riordan and Weatherly (1999); Roccas (2003); Smidts, Pruyn, and Van Riel (2001); Vandenberg, Self, and Seo (1994); Van Dick, Wagner, Stellmacher, and Christ (2004); Van Knippenberg, van Knippenberg, Monden and deLima (2002); Van Leeuwen, van Knippenberg, and Ellemers (2003)

Note 5. According to Hinkin (1998), the model is useful when the chi-square value is three times less than the degree of freedom.

\section{Copyrights}

Copyright for this article is retained by the author(s), with first publication rights granted to the journal.

This is an open-access article distributed under the terms and conditions of the Creative Commons Attribution license (http://creativecommons.org/licenses/by/3.0/). 